Article

\title{
Music, Migration, and Public Space: Syrian Street Music in the Political Context
}

\author{
Evrim Hikmet Öğüt
}

check for

updates

Citation: Öğüt, Evrim Hikmet. 2021. Music, Migration, and Public Space: Syrian Street Music in the Political Context. Arts 10: 71. https:// doi.org/10.3390/arts10040071

Academic Editor: Florian Scheding

Received: 21 June 2021

Accepted: 18 October 2021

Published: 22 October 2021

Publisher's Note: MDPI stays neutral with regard to jurisdictional claims in published maps and institutional affiliations.

Copyright: (C) 2021 by the author. Licensee MDPI, Basel, Switzerland. This article is an open access article distributed under the terms and conditions of the Creative Commons Attribution (CC BY) license (https:/ / creativecommons.org/licenses/by/ $4.0 /)$.
Musicology Department, Mimar Sinan Fine Arts University, Istanbul State Conservatory, Istanbul 34357, Turkey; evrim.hikmet.ogut@msgsu.edu.tr

\begin{abstract}
Due to the lack of social systems supporting the cultural productions of migrant societies in Turkey, the venues and opportunities to which migrant musicians have access for the maintenance of their musical practices are limited. Under the given circumstances, especially in the first years after their arrival, street musicianship emerged as a new musical practice for Syrian musicians in Istanbul, and Beyoğlu District, the city's cultural and political center, has become the venue for street musicians' performances. Despite undergoing a rapid neoliberal transformation, Beyoğlu district, with Taksim Square and Istiklal Avenue, is a venue of interaction among locals, tourists, and various migrant groups from diverse social classes and identities. As such, it still possesses the potential to be the public sphere which can operate as the space of "a democratic ideal." For migrant musicians, the street music practices, which fill the very heart of city with their voices and sounds, are means of claiming their existence in the city as potential actors of this public sphere. However, conducting the interaction with the other public space actors and the state officials through street music is not an easy task for Syrian musicians, and it requires the use of tactics from them. In this article, I summarize the given circumstances of Syrian street music performances and discuss the Beyoğlu district in the frame of being —or not being — a public space. I propose street music practice as political action, a "social non-movement", as Asef Bayat calls it, and situate migrant musicians as political actors who are possible allies of other subaltern groups in Turkey.
\end{abstract}

Keywords: Syrian musicians; street musicianship; public space; social non-movement

\section{Introduction}

It was on a sultry afternoon in summer 2016 when we met with Osama and Mahdy in Taksim Square. Osama was carrying his violin case, and Mahdy had his cajon in a cloth bag. We chatted while they were looking for a spot for their daily performance on Istiklal Avenue. As soon as they chose a place in front of an empty building, a municipal police officer approached to tell them to "play somewhere else." We started walking again. There were many other Syrian and Iranian bands on the street playing at various spots. We stopped for a while to greet the members of another band, Watan - meaning "country" — formed by Syrian musicians in Istanbul. Shortly after, we had found a convenient spot for performance in the middle of the street, an undercover police officer appeared and said they could not play there. After the third attempt similarly failed, I asked if they have the same experience every day, and Mahdy replied smiling, "You see, they want to exile us to the border by doing this!"

This story summarizes the daily struggle of not only the Syrian ${ }^{1}$ musicians in Istanbul but also many Syrian migrants ${ }^{2}$ in Turkey. Based on the agreement between the European Union and Turkey dated March 2016, ${ }^{3}$ Syrian migrants became permanent residents of the country; yet they still do not have a permanent status. However, it is not only their legal status that reminds them of their temporality. Human Rights organizations reported illegal deportations in July and October $2019^{4}$ and in February 2020 as a "response" to the attacks against Turkish troops in Syria; the Turkish government declared that Tukey would no 
longer stop the Syrian migrant flow to Europe. ${ }^{5}$ These cases show that, depending on the Turkish government's Syrian policy and the European Union's border regime, temporality and permanency are still obscure concepts in Turkey's Syrian migratory experience, and the only steady fact in the dense history of Syrian migration is instability.

Most Syrian migrants in Turkey live and work under temporary, insecure, lowpaid, and precarious conditions, along with the labor market's most vulnerable actors (Şenses 2016). Thus, as Ilcan et al. (2018) state, the "permanent temporariness" of Syrian migrants is not only due to their obscure legal status in Turkey but also because they are confronted by various forms of precarity (p. 56).

In the first years of the migration, working in textile mills or construction sites were the only possibilities for many Syrian migrants, including musicians. However, from 2014 onwards, Syrian musicians facing these working conditions took to playing in the streets of Istanbul to earn their living through music. Soon after, this became their primary source of income and, over time, has begun to operate as the first step of a new, alternative music market which they built in the city.

In addition to being an economic activity, ${ }^{6}$ I consider the street practices of Syrian musicians as a tool they use to incorporate themselves into the public space. In this respect, this article proposes street music practice and its use of the public space as a political act and focuses on migrant musicians as political actors. ${ }^{7}$ I discuss their appearance in the public space referring to Richard Sennett's ([1977] 2002) analogy between the street and the stage. By reading his analogy in a broader framework, I imagine Syrian musicians as actors who participate in the conversation on this stage, not by talking (through language) but by singing (through music); when considering their lack of language skills in the first years of migration, the stage analogy becomes even more accurate. I also propose that being actors in public spaces requires them to develop new skills. While explaining these skills, or, in other words, their choices and acts on this stage, I apply the term "tactic" as employed by Michel De Certeau (1984), who suggests it as a tool of the subordinate in dealing with daily power relations. Lastly, I argue that this musical practice is a political act in itself. I discuss street music in the frame of "social non-movements" that Asef Bayat (2012) contextualizes while describing the subaltern's political action in a city shaped by the neoliberal market economy.

Although I do not directly refer to my interlocutors' testimonies, this article is based on long-term field research from late 2015 to the present. The time period covered in this article, which I call "the heyday of street music", extends into the summer of 2018. After that year, street music practices diminished for various reasons, and the street gave way to other musical venues. One of those reasons is the settlement of the Syrian community as de facto permanent residents in Turkey and the establishment of diverse new musical contexts for themselves. Despite the diminishing of street performances, Syrian musicians did not disappear. On the contrary, their agency can be seen in the foundation of new musical contexts beyond the scope of this article. The COVID-19 pandemic, on the other hand, as for musicians around the world, has also impacted Syrian musicians. Even though some musicians revisited the street, street music has not returned to its heyday.

\section{Syrian Street Musicianship in Istanbul}

Even though the Syrian migration started in 2011, the flow gained momentum in 2014, with the Syrian population in Turkey increasing from around 200,000 to 1.5 million in 1 year. $^{8}$ Thus, 2014 can be considered as the beginning point for the Syrian population's visibility in the country. In the summer of the same year, Syrian musicians started street performances in Taksim Square and Istiklal Avenue. Soon after, street musicianship became one of the primary musical and economic activities of Syrian musicians who prefer to earn their living through musical performances instead of other low-income jobs. In parallel to the increase in the number of Syrian refugees in the country, during 2015 and 2016, the number of Syrian musicians in Taksim Square and Istiklal Avenue increased. Consequently, 
through their street musicianship practice, Syrian musicians became more and more visible in Istanbul's city center.

Despite the fact that street music practices are seen as inferior in Syria, the lack of alternatives for performing music, particularly as a source of income in Istanbul, soon led many Syrian musicians to adopt the practice. By summer 2016, it was possible to come across around 20 Syrian musicians on Istiklal Avenue, with their guitars, ouds, various percussion instruments, violins, and qanuns, playing and singing as groups on a single day. Several were professionals with degrees from the conservatoire in Damascus or the music education faculty at Homs or musicians who had had a professional music career in Syria. Some were amateurs who became professional musicians under the migratory conditions in Istanbul. They were largely acquainted from Syria and were informed about this musical practice in Istanbul via migrant networks. Street musicianship was a brand-new experience for all of them. Almost all were from Arabic ethnic backgrounds, and they were all male. ${ }^{9}$

\section{Taksim Square and Istiklal Avenue as Public Space}

Philip Bohlman (2002) reminds us that "The modern city gave the individual a greater degree of freedom to move about in the public spaces of the metropolis, and one of the most common forms of encounter is between the individual and the public spaces through which she or he has the freedom to move" (p. 134). Syrian migrants, like other inhabitants of the city, have access to public spaces. However, the condition of public space in Istanbul and the degree of migrants' involvement in the public space requires a multi-layered discussion. Accordingly, the discussion in this article is limited to musicians' incorporation into public space through music practices in Taksim Square and Istiklal Avenue.

While discussing street music practices as a means of operating in the public space, it is crucial to understand the Beyoglu district's sociopolitical relevance in general. This information is also critical in understanding why Syrian musicians choose it as almost the sole venue for their performances, although street music is also practiced in some other parts of the city. Beyoğlu district, with its historical name, Pera, and which includes Taksim Square and Istiklal Avenue, has been the center of multicultural trade and entertainment since the Ottoman period. In the 19th century, the avenue, Cadde-i Kebir (Big Avenue), was full of cafés, theatres, book stores, and photography studios, mostly run by non-Muslim minorities, and it was not a coincidence that the first municipality was established in Beyoğlu district in 1857 (Baykan and Hatuka 2010, p. 53). In the early 20th century, after the Republic's foundation, the avenue's name was changed to Istiklal (Independence) Avenue. With the erection of the Republic Monument in 1928, Taksim Square was re-constructed and defined as the symbol of the modern state's public space in Istanbul (Zeybekoglu Sadri 2017). In the following years, due to the systematic Turkification, especially after the Istanbul Pogrom in $1955,{ }^{10}$ the street lost its distinctive characteristics.

Taksim Square has also been the venue of mass politics throughout its history and witnessed one of the most tragic massacres in Turkey at the May Day celebration in $1977 .{ }^{11}$ However, since the military coup of 1980, liberalization, the economic ideology globally, has shaped Taksim Square as well as cultural life in general. ${ }^{12}$ Thus, along with expressions of mass politics, the square has become a touristic center and a global cultural center.

In the early 1990s, with new regulations including pedestrianizing the street and re-establishing the historical tramway, the street regained its character as a cultural and artistic center, with bookstores, movie theaters, etc. In the 1990s and early 2000s, echoing globalization and neoliberal economic relations, Istanbul began to take its place in the world music scene (Değirmenci 2008). Apart from the world music events that new music venues host, with the contribution of local and foreign/migrant musicians-mostly from European countries at that time-Istiklal Avenue turned into a multi-cultural festival scene. However, in the last two decades, the neoliberal, authoritarian regime has attacked the district with gentrification and various symbolic construction projects. While one of those projects, the replication of an Ottoman military barracks in Gezi Park, was defeated in 2013, 
another one, the construction of a huge mosque in the Square, was accomplished in 2019 (Hammond 2019).

Baykan and Hatuka (2010), in their article on the changing political meaning of Taksim Square throughout history, state that "the city centers, squares, and streets, on the one hand, have become representational symbols in the elitist discourse of nationalist and totalitarian ideas of a unified society aiming for modernization and, on the other hand, the territories on which masses of people express their own conflicting demands" (p. 49). Similarly, in addition to being the subject of nation-state politics or operating as a touristic and trade center, Taksim Square has been the venue of political demonstrations and, especially after May Day 1977, gained a symbolic meaning for the Turkish left. Istiklal Avenue, too, has been the host to various protests for decades. The Gezi protests in 2013, for example, started at Gezi Park next to the Square (Batuman 2015).

After the Gezi movement was suppressed and with the new political climate in the country, Taksim Square and Istiklal Avenue, day by day, became closed to political demonstrations. This period was followed by the failed military coup attempt in 2016. Since then, all kinds of social protests have been forbidden (Gökarıksel and Türem 2019). Consequently, today, Taksim Square does not function as a "public sphere" in the Habermasian context, in which people can discuss and manifest their political demands (Habermas et al. 1974). Currently, Beyoğlu operates as a highly commercialized touristic center. In Richard Sennett's contextualization of public space, the city's transformation, urban planning, and architecture have an essential place. According to him, the transformation of the city directs inhabitants to a certain degree of isolation and to "seek out an intimate terrain" (Sennett [1977] 2002, p. 15), which is the reason for the "fall of the public man." In this contextualization, Beyoğlu today can be described as a "dead public space".

However, with thousands of city dwellers from various social backgrounds and the tourists who visit the Square and the street every day, Beyoğlu is still a space of encounter. As a venue of interaction among locals, tourists, and various migrant groups from diverse social classes and identities, its potential to create a democratic ideal can be assumed, again considering Sennett's representation of the city. Sennett defines the city as a public space that gives room for the interaction of people from various social and cultural backgrounds, where they can create thinking, discourse, actions, and struggles collectively without hiding personal differences or imposing themselves onto each other. Thus, the city is not the place of uniqueness, but rather, a public realm composed of "people looking on each other, who are strangers and who are impersonal" (Sennett 2011, p. 396). In this respect, the city is the venue for democratic relations. It allows encounters between strangers, including minorities and migrants, and these encounters pave the way for learning from one other.

Sennett asserts that, by the 19th century, the reduction of social relations to commercial and touristic relations disidentifies the city. Meanwhile, the inhabitants become quiet and withdrawn. They realize that the only possible way of being involved in city life is staying silent. A similar case of the silencing of public life in Taksim coincides with the period of the Syrian migrants being visible and Syrian musicians starting to perform on the street. In other words, while Syrian musicians were incorporating themselves into the public space, the citizens were gradually withdrawing from the street under the neoliberal transformation and the political depression after the Gezi protest. After the failed coup attempt in July 2016, the political oppression was amplified, and any demonstrations in which people could raise their demands against authority became forbidden. Subsequently, public spaces in the city center such as Taksim Square were rapidly taken over by pro-government actors and the "democracy watches" organized by the government. Consequently, in Sennett's description, the public space in which the Syrian musicians appeared can be described as the very example of dead publicity, in which people were distanced from discussing their democratic demands. 


\section{Acting on the Public "Stage"}

Due to the increasing number of tourists from Arabic-speaking countries, ${ }_{13}^{13}$ in the first years of their street music practices, the Syrian musicians' primary income source was tourists. However, in my ethnographic interviews, the Syrian musicians' emphasis on seeking interaction with the Turkish citizens was remarkable. ${ }^{14}$ Therefore, I can state that Syrian musicians who were aware that their future would take place in Turkey were at least seeking to address the locals. Playing their instruments, singing in their language, and filling the city's center with their voices, they claim their presence and offer a communication channel to local residents.

While describing the parallelism between the street and the stage, Sennett ([1977] 2002) mentions the rules that govern responses to the stage (p. 38). To navigate the unequal power relations between citizens and themselves, Syrian musicians used various tactics to follow, learn, or reform these rules. Discussing the power relations in everyday life, Michel De Certeau (1984) uses the concepts of strategy and tactics. He describes strategy as a tool to maintain the given power relations in its domain. Tactics, on the other hand, are the tools of the "weak" or subordinate. Several daily practices of the subordinate can be seen as tactics to act in the sovereign's domain (p. xix). Keeping in mind that Nancy Fraser (1990) reminds us that the public sphere has always been the space of societal inequalities (p. 66), we can assume that any encounter in the public space requires following some tactics to deal with the power relations in social interaction.

Syrian musicians use various tactics in interacting with the police, municipal police, shopkeepers, other musicians, citizens, and tourists. These tactics vary from choosing a proper spot to have the audience that will provide optimum income, to choosing the proper repertoire, to keeping themselves safe. While discussing the city as the locality of world music, Philip Bohlman (2002) notes that the physical topography of the metropolis increases the opportunities for encounters, and no one navigates these more skillfully than street musicians (pp. 134-135). Concerning street musicians' marketing strategies, he states that they know exactly where to place their portable stages to draw the most generous audiences. He adds that musicians know which repertories will appeal to the old and new residents of the city and how they are cautious about not highlighting long-standing tensions between diverse actors (p. 131).

Street musicians, then, are very aware of their audience profile. Adjusting the repertoire to impress a diverse audience is one of the most significant matters that Syrian street musicians face, and they do so meticulously. Since tourists from Arabic-speaking countries constitute a large portion of the audience, playing well-known Arabic songs from the broader Arab geography is very common for bands of Syrian musicians; they usually play the songs consecutively and faster than their original style. However, some songs of the Lebanese singer Fairouz, which have had Turkish arrangements from the 1970s, are played not only for this Arab audience; they aim to attract Turkish people also, for example, by singing the refrains of those songs with Turkish lyrics.

Conducting the fluid crowd is not only a marketing issue. It also requires musicians to play a "role" on the "stage" of the street, which is even more vital while keeping themselves safe and secure in an environment that is not always friendly. The interventions of police, municipal police, shopkeepers, and possible malicious behavior by the pedestrians is a crucial issue that compels them to develop coping tactics. In summer 2016, at the same time that the street performances of Syrian musicians reached their peak, a military coup attempt changed the political climate in the country. The social atmosphere after this occasion caused one of the most severe attacks on Syrian businesses in Ankara (Baban et al. 2016, p. 83). The tactic Syrian musicians developed to keep themselves safe was striking: Wearing Turkish flag-printed t-shirts while playing on the street, for a week, sometimes even longer. On the one hand, this extraordinary example reveals the fragility of Syrian refugees in Turkey, but it also showcases their determination to continue their performances and their capacity to develop tactics to cope with this inescapable reality. 


\section{Social Non-Movements}

As ethnomusicologist Martin Stokes (2018) points out, the city simultaneously restricts and fosters the movements of marginal communities, including migrants. Following this reality, numerous ethnomusicological studies focus on the agency and mobility of migrant communities in urban settings. A discussion around the concept of "citizenship", which has its roots in a critical trend that emerged in the 1990s in migration studies, offers a new understanding of the term by expanding the definition of citizenship from a discussion of its legal status to a focus on experience. This approach also has a significant place in recent ethnomusicological studies. Stokes (2018) reminds us that citizenship is an empirically shaped notion instead of an exclusionary understanding in neoliberal nation-state politics (p. 19) and employs the concept of "musical citizenship" in seeking answers to how music can create new democratic feelings and new ways of being a citizen (p. 25). In a similar vein, ethnomusicologist Michael O'Toole (2014) offers the concept of "sonic citizenship" in the migratory context in modern Germany, describing it as a type of political involvement through sounds—such as musical performance or sonorous ritual—to create public interventions in a context defined by unequal access to political and social power. Tom Western (2020), likewise mentioning "sounding citizenship", discusses the notion of citizenship in the context of Europe, in the case of the inclusion and exclusion of the sound of refugee communities in Athens. In this respect, a concept of citizenship that leans on human experience, mobility, and agency, including the cultural domain, provides a useful tool for discussing the presence of migrant musicians in public life. However, another critical tendency in migration literature suggests that the attempt to broaden the definition of citizenship is ultimately problematic since it underestimates citizenship's exclusionary nature (Ataç et al. 2016, pp. 532-33).

For my discussion of the street musicianship of Syrian migrants in the public space in the political context, I refrain from employing an approach in favor of cultural citizenship. Instead, I explore the concept of social non-movement, referring to the approach of sociologist Asef Bayat. ${ }^{15}$ Having said that, social non-movements are not irrelevant to the claim on various forms of citizenship. As Bayat points out (2013), the struggle of non-movements of this sort can be seen as a struggle for the citizenship of marginalized people. Citizenship de facto occurs when the non-movements achieve their aims against the state's resistance, and it may even be followed by citizenship de jure when the achievements are legally acknowledged in state statutes (p. 23). In her examination of the social movements of Middle Eastern societies, Bayat brings forth a refreshing perspective that challenges the general belief of the limited agency of subaltern voices in the public space. Beyond an understanding of social movements in the realm of social movement theory regarding Western societies, Bayat (2012) sees a potential of a discrete form of politics in the societies he focuses on.

According to a widely used definition by Tilly and Tarrow (2015), a social movement is a "sustained campaign of claim making, using repeated performances that advertise the claim, based on organizations, networks, traditions, and solidarities that sustain these activities" (p. 11) ${ }^{16}$ Referring to the given components of social movements, Bayat questions the likelihood of developing and sustaining such movements in the context of "non-Western politically closed and technologically limited settings." In this regard, he suggests social non-movements as a brand-new approach that rejects both Middle Eastern "exceptionalism", which tends to picture the Muslim Middle East as a monolithic and static entity, and the conventional social science concepts that are rooted in the Western context (Bayat 2013, p. 5).

First of all, Bayat (2013) addresses the urban public space as "the key theater of contentions" (p. 12). Therefore, the street is the ultimate stage for expressing dissatisfaction, especially for those who lack institutional capacity (jobless, housewives, and "informal people"). Streets, on the other hand, are the places where these people form identities, expand solidarities, and extend their protest to strangers. Streets serve as a means for strangers or passersby to communicate through their shared interests and emotions. This 
potential also makes it possible that a small demonstration may grow into a massive one in some instances (Bayat 2013, p. 13). According to Bayat (2012), social non-movement as the "collective action of non-collective actors" (p. 121) thus occurs in the daily life experiences of subalterns, and is an attempt to be involved in a relation of power over the control of public space and public order, such as the "poor peoples' resolve to migrate, build shelters, or work, live, function and stroll in streets; and the illegal migrants' acts of crossing borders, finding work and looking for livelihoods" (p. 124), which exemplify attempts to remain free from suppression.

Lastly, Bayat sees neoliberal cities, which are shaped by the logic of the market, as the main venues of this kind of social politics. The subaltern groups who are left to survive in the neoliberal economy do not withdraw; on the contrary, they "stretch out" and claim the streets. They become actors of an informal outdoor economy that is formed under neoliberal conditions. He also mentions a withdrawal of public space actors, as Sennett does. However, according to Bayat (2012), as a response to the stretching out of the subalterns, enclosure is seen in the lives of the city elites, who withdraw to their safe residences. Thus, this is a "city-inside out" (p. 113), in which the subalterns claim while the elites withdraw.

Along with the rural migrants who assert their "right to city", Bayat (2013) addresses international migrants as among the prominent actors of social non-movements. Despite the border checks, barriers, gates, walls, and police patrols, they continue arriving - by boats, trucks, rail, or foot. They settle, find employment, buy houses, have families, and fight for legal protection in the cities of the global North. They create communities and religious and cultural centers and become visible in the public spaces. As far as they feel safe and secure, they express their physical, social, and cultural presence in the host societies (p. 16).

\section{Street Music Performances as Social Non-Movements}

The lower status - as equivalent to begging — of any street practices including musical performances in Syria is a cultural fact that one can hear from every single Syrian musician. As a result of this cultural bias, some musicians refuse to play on the street or are reluctant to accept doing so (Hajj 2016; Shannon 2019; Habash 2021; Öğüt forthcoming). Given this substantial cultural and moral obstacle to adopting street musicianship as the main breadwinning activity, doing so is a conscious decision for Syrian musicians, which highlights their agency in positioning a new urban setting in Istanbul. Referring to the street and bar performances of Syrian musicians in Istanbul, Dunya Habash (2021) examines the musical performances of Syrian music in Istanbul in the context of place making and "emplacement" into a new society through music. She points out an alternative form of resistance and resilience in adopting street music practices and in maintaining performances at "inappropriate" venues. She states that, in the course of her study, while searching for external manifestations of resilience and resistance, such as anger and rebellion, she found another dimension to the idea of agency in which cultural taboos are overcome to adjust to the new host environment (1372). I agree with Habash's observation and argue that performing on the street and maintaining this practice with precise tactical choices is nothing less than a form of political action, which, beyond resilient and resistance practices, represents a declaration of presence and a claim for the city. This action is neither passive nor silent.

In order to perceive the political dimension of street music practices, it is crucial to portray the position of Syrian migrants and their capacity for agency against various political layers in Turkey. Syrian migrants in Turkey are deprived of the conventional means of political action. First of all, in Turkey, Syrian migrants are not described as refugees or subjects who have certain rights with a rights-based migration policy. Due to their temporary status, they are seen as humanitarian assistance subjects rather than political agents with rights (Baban et al. 2017; Genç et al. 2019), and they lack access to the means of participatory democracy. Secondly, the Turkish Law on Foreigners and International 
Protection, which also describes the Temporary Protection regulations that Syrian migrants are subjected to, clearly states that "[A] foreigner or a stateless persons [sic] in respect of whom there are serious indications of posing a public order or public security threat, as well as a foreigner or a stateless person outside the scope of subparagraph (c) of the first paragraph who has previously committed a serious crime for which imprisonment would have been ordered if committed in Turkey, and have left his/her country of origin solely to avoid punishment for that crime, shall be excluded from subsidiary protection" (The Law on Foreigners and International Protection 2014, p. 67). This blurred description of crime against "the public order and public security" is the most significant obstacle concerning migrants' political actions in the sense of conventional social movements that are defined by components such as an organized and sustained claim, a performance repertoire, organizations, public meetings, statements by media, street demonstrations, and the public representations of the movement.

In such a view, as Asef Bayat suggests in the context of the marginalized, poor actors of the neoliberal cities in Middle Eastern countries, the social non-movement through daily practices is, if not the only, one of the most critical political means for Syrian migrants in Turkey. Syrian musicians become involved by participating in the public space as active agents through music performances and make their voices audible in every sense.

\section{Conclusions}

By performing in Taksim Square, the center of the city, Syrian musicians resist the various obstacles that disallow them from attending the music market in Turkey and overcome those obstacles by applying a brand-new musical practice for themselves: street musicianship. This practice's uniqueness and function as a first stage in forming a new, alternative music market needs to be discussed further. However, the street musicianship of Syrian musicians has a very peculiar social and political meaning in that it affords migrants involvement in public spaces as proactive actors. With the tactics migrant musicians develop and employ by acting in the public space, street music practice can be seen as a political act through which musicians declare their existence in the city center. Considering that Syrian migrants mostly live in the city's periphery, their existence and visibility through street performances in the city center is worthy of attention. Moreover, even though staying silent is primarily a safety precaution for migrants, and their fragile legal status compels them to political voicelessness, this musical act with which they fill the city center loudly with their sounds and voices gains even more significance as a claim, a political act, and a social non-movement, as Bayat proposes.

The social non-movements of various subaltern groups cannot be seen as separate, isolated movements; they expand the possibilities of each other's struggles. Just as there is no singular Syrian or migrant identity in Turkey, citizenship privileges are not enjoyed in the same way by various local subalterns. Hence, the neoliberal economy that left migrants to their survival and obliges them to precarity operates similarly for many citizens. Richard Sennett sees the reformation of public space as an antidote to this closure. Additionally, Nancy Fraser reminds us that discrimination and inequalities in public spaces create counter-public spaces that interact in multiple ways. In this respect, reforming a "democratic" public space cannot be considered without including migrant communities. Considering this reality, for those who intend to reform and reclaim public space in Turkey, it is necessary to recognize the subaltern's social non-movements and give an ear to Syrian musicians' voices.

Funding: This research received no external funding.

Institutional Review Board Statement: Not applicable.

Informed Consent Statement: Not applicable.

Data Availability Statement: Not applicable.

Conflicts of Interest: The author declares no conflict of interest. 


\section{Notes}

1 In this article, the term Syrian is used with reservation regarding its inadequacy and reductiveness in describing this nonhomogenous migrant community from Syria.

2 According to Turkey's migration policies, Syrian migrants do not have refugee status as they should but are under "temporary protection." This temporary protection status constantly asserts that Syrian migrants are "temporary guests" in the country.

3 For the full text of the joint statement of the EU and Turkey, see (EU-Turkey Statement 2016).

4 (Amnesty International 2019).

5 (Reuters 2020).

6 For a detailed article on the street music practice of Syrian migrants in Istanbul, see: (Öğüt forthcoming).

7 For a comprehensive overview of the Street music practice of Syrian musicians in Istanbul, see: (Öğ̈ut forthcoming).

8 (Republic of Turkey Ministry of Interior Directorate General of Migration Management 2021).

9 The ethnic and gender aspects of Syrian Street musicianship and the lack of women musicians in the public space is examined in another article, see: (Ögüt forthcoming).

10 The events are known as "The Events of 6-7 September". On the night of 6-7 September 1955, organized mob attacks against the city's ethnic minorities, especially targeting the Greek and Armenian populations, occurred. On 6 September 1955 , riots broke out, with the destruction and looting of tens of thousands of properties, including homes, large and small businesses, factories, churches and schools, two monasteries, and a synagogue. The overwhelming majority belonged to ethnic Greeks, but there were also those of Armenians, Jews, and Muslims. The crowd attacked several businesses and homeowners, resulting in beatings, assaults, and deaths. The exact number of casualties is unknown; deaths from beatings or being trapped by fire are estimated to be between 15 and 37 .

11 The first massive May Day celebrations took place at Taksim Square in Istanbul in 1976. In 1977, 37 participants lost their lives when gunfire was opened on people attending the celebration; the perpetrators remain unknown. After this tragic incident, Taksim Square was closed to the May Day celebrations. However, as the Square has a symbolic meaning since the massacre in 1977 and is a significant public sphere in the collective memory, unions and leftist organizations have been insisting on celebrating the day in the Square for years.

12 Ataturk Cultural Center (Atatürk Kültür Merkezi/AKM), located on Taksim Square, had a very significant impact on the city's cultural life. The center, re-opened in 1978 (it was founded in 1969 but stayed closed for eight years after a fire in 1970), hosted the Istanbul State Opera and Ballet and Istanbul State Symphonic Orchestra along with other various art ensembles under the Ministry of Culture and Tourism and operated as the main venue of Western music culture in Turkey. Since it was vacated in 2008 and not renovated for 10 years (it was demolished in 2018 for a reconstruction), AKM is at the center of a vivid discussion directed at a secular-conservative dichotomy.

13 (Republic of Turkey Ministry of Culture and Tourism Border Statistics 2020).

14 For an interview series with Syrian musicians in Istanbul made by Evrim Hikmet Öğüt and Umut Sülün (videographer), see: www.soundsbeyondtheborder.org (accessed on 21 October 2021).

15 In this article, my aim is not to discuss social movements in a theoretical frame, nor migrant protests and migrant solidarity movements in general. For the latter, see: (Steinhilper 2021; Ataç et al. 2017). I rather apply a particular approach that I find very appropriate to my case study.

16 However, there are rejections of Tilly and Tarrow's definition, primarily as they place the government as the target of social movements; thus, it should be understood as a dynamic concept like many others.

\section{References}

Amnesty International. 2019. Turkey Sent to a War Zone: Turkey's Illegal Deportations of Syrian Refugees, Report. Available online: https:/ / www.amnesty.org/en/documents/eur44/1102/2019/en/ (accessed on 29 January 2021).

Ataç, Ilker, Kim Rygiel, and Maurice Stierl. 2016. Introduction: The Contentious Politics of Refugee and Migrant Protest and Solidarity Movements: Remaking Citizenship from the Margins. Citizenship Studies 20: 527-44. [CrossRef]

Ataç, Ilker, Kim Rygiel, and Maurice Stierl, eds. 2017. The Contentious Politics of Refugee and Migrant Protest and Solidarity Movements: Remaking Citizenship from the Margins. Basingstoke: Routledge. [CrossRef]

Baban, Feyzi, Suzan Ilcan, and Kim Rygiel. 2016. Syrian Refugees in Turkey: Pathways to Precarity, Differential Inclusion, and Negotiated Citizenship Rights. Journal of Ethnic and Migration Studies 43: 41-57. [CrossRef]

Baban, Feyzi, Suzan Ilcan, and Kim Rygiel. 2017. Playing Border Politics with Urban Syrian Refugees. Movements Journal for Critical Migration and Border Regime Studies 3: 81-102.

Batuman, Bülent. 2015. 'Everywhere Is Taksim': The Politics of Public Space from Nation-Building to Neoliberal Islamism and Beyond. Journal of Urban History 41: 881-907. [CrossRef]

Bayat, Asef. 2012. Politics in the City-Inside-Out. City and Society 24: 110-28. [CrossRef]

Bayat, Asef. 2013. Life as Politics: How Ordinary People Change the Middle East. Stanford, CA: Stanford University Press. 
Baykan, Aysegul, and Tali Hatuka. 2010. Politics and Culture in the Making of Public Space: Taksim Square, 1 May 1977, Istanbul. Planning Perspectives 25: 49-68. [CrossRef]

Bohlman, Philip V. 2002. World Music: A Very Short Introduction. New York: Oxford University Press.

De Certeau, Michel. 1984. Practice of Everyday Life. Berkeley: University of California Press.

Değirmenci, Koray. 2008. Turkish World Music: Multiple Fusions and Autenticities. Ph.D. thesis, Middle East Technical University, Ankara, Turkey.

EU-Turkey Statement. 2016. Available online: https://www.consilium.europa.eu/en/press/press-releases/2016/03/18/eu-turkeystatement (accessed on 26 January 2021).

Fraser, Nancy. 1990. Rethinking the Public Sphere: A Contribution to the Critique of Actually Existing Democracy. Social Text 25/26: 56-80. [CrossRef]

Genç, Fırat, Gerda Heck, and Sabine Hess. 2019. The Multilayered Migration Regime in Turkey: Contested Regionalization, Deceleration and Legal Precarization. Journal of Borderlands Studies 34: 489-508. [CrossRef]

Gökarıksel, Saygun, and Z. Umut Türem. 2019. The Banality of Exception? Law and Politics in 'Post-Coup' Turkey. South Atlantic Quarterly 118: 175-87. [CrossRef]

Habash, Dunya. 2021. 'Do Like You Did in Aleppo': Negotiating Space and Place among Syrian Musicians in Istanbul. Journal of Refugee Studies 34: 1370-86. [CrossRef]

Habermas, Jürgen, Sara Lennox, and Frank Lennox. 1974. The Public Sphere: An Encyclopedia Article (1964). New German Critique 3: 49-55. [CrossRef]

Hajj, Hussain. 2016. The Syrian Musicians in Istanbul: The Relationship between Repertoire and Stage. Alternatif Politika 8: 474-84.

Hammond, Timur. 2019. The Politics of Perspective: Subjects, Exhibits, and Spectacle in Taksim Square, Istanbul. Urban Geography 40: 1039-54. [CrossRef]

Ilcan, Suzan, Kim Rygiel, and Feyzi Baban. 2018. The Ambiguous Architecture of Precarity: Temporary Protection, Everyday Living and Migrant Journeys of Syrian Refugees. International Journal of Migration and Border Studies 4: 51. [CrossRef]

O’Toole, Michael Francis. 2014. Sonic Citizenship: Music, Migration, and Transnationalism in Berlin's Turkish and Anatolian Diasporas. Ph.D. thesis, The University of Chicago, Chicago, IL, USA.

Öğüt, Evrim Hikmet. forthcoming. Syrian Street Music in Istanbul: Challenges and Potentials. Journal Music and Minorities.

Republic of Turkey Ministry of Culture and Tourism Border Statistics. 2020. Yearly Bulletins. Available online: https://www.ktb.gov. tr/EN-249299/yearly-bulletins.html (accessed on 20 December 2020).

Republic of Turkey Ministry of Interior Directorate General of Migration Management. 2021. Temporary Protection Statistics. Available online: https: / / en.goc.gov.tr/temporary-protection27 (accessed on 14 December 2020).

Reuters. 2020. Turkey will no Longer Stop Syrian Migrant Flow to Europe: Turkish official. Available online: https: / / www.reuters.com/article/us-syria-security-turkey-migrants/turkey-will-no-longer-stop-syrian-migrant-flow-to-europeturkish-official-idUSKCN20L33V (accessed on 29 January 2020).

Sennett, Richard. 2002. The Fall of Public Man. New York: Penguin Books. First published 1977.

Sennett, Richard. 2011. Reflections on the Public Realm. In A New Blackwell Companion to the City. Edited by Garu Bridge and Sophie Waton. West Sussex: Blackwell Publishing, pp. 390-398. [CrossRef]

Şenses, Nazlı. 2016. Rethinking Migration in the Context of Precarity: The Case of Turkey. Critical Sociology 42. [CrossRef]

Shannon, Jonathan H. 2019. From Silence into Song: Affective Horizons and Nostalgic Dwelling among Syrian Musicians in Istanbul. Rast Müzikoloji Dergisi 7: 2169-80. [CrossRef]

Steinhilper, Elias. 2021. Migrant Protest: Interactive Dynamics in Precarious Mobilizations. Amsterdam: Amsterdam University Press. [CrossRef]

Stokes, Martin. 2018. The Musical Citizen. Ethnomusicology Journal 1: 15-30.

The Law on Foreigners and International Protection. 2014. Available online: https://drive.google.com/file/d/1smvKEb0xIjFjk0m_ YeDPvX8hS0eVFtfs/view (accessed on 28 January 2021).

Tilly, Charles, and Sidney Tarrow. 2015. Contentious Politics. New York: Oxford University Press.

Western, Tom. 2020. Listening with Displacement. Migration and Society 3: 194-309. [CrossRef]

Zeybekoglu Sadri, Senem. 2017. The Scale of Public Space: Taksim Square in Istanbul. Journal of Contemporary Urban Affairs 1: 67-75. [CrossRef] 